\title{
Business Diversification, BUMDes Bonto Sunggumanai Strategy to Survive During the Pandemic
}

\author{
Najmi Kamariah, Murtafia*, Ahsan Anwar \\ Politeknik STIA LAN Makassar \\ Makassar, Indonesia \\ *murtafia@stialanmakasar.ac.id
}

\begin{abstract}
Companies whose main orientation is profit are diversifying their businesses with the aim of increasing opportunities to generate profits from the various businesses they run. BUMDes Bonto Sunggumanai actually did something different. BUMDes Bonto Sunggumanai, which is a village-owned enterprise, is diversifying its business with the aim of surviving the pandemic. Bumdes Bonto Sunggumanai is a village-owned enterprise whose main orientation is profit which is used to improve the welfare of the village community as well as the source of village income. This study aimed to describe how BUMDes located in Gowa Regency, South Sulawesi maintain their business during the pandemic period through a business diversification strategy. The research method uses descriptive qualitative approach. The research focused on five business units from various sectors such as village financial institutions, agricultural trade, online payment services, small industries and agribusiness and horticulture business units. Five business units were selected by looking at the potential of village resources, residents' needs and business sustainability for 1 year. The results of the study concluded that the business diversification strategy being carried out was able to help BUMDes to survive during this pandemic.
\end{abstract}

Keywords-survival strategy, business diversification, village owned enterprise (BUMDes)

\section{INTRODUCTION}

Village-Owned Enterprises (BUMDes) are village business institutions managed by the community and village government in an effort to strengthen the village economy and are formed based on the needs and potential of the village. In the Regulation of the Minister of Home Affairs Number 39 of 2010 concerning Village-Owned Enterprises, it is stated that one of the objectives of establishing BUMDes is, among others, to increase the financial capacity of the village government in government administration and increase community income through various economic business activities of rural communities according to the needs and potential of the village.
The Covid 19 outbreak that hit all countries had an impact on decreasing economic growth. Almost all sectors experienced negative growth. The Policy of PSBB (LargeScale Social Restrictions) that is implemented in most parts of Indonesia has an impact on the company's operational sustainability. The company carries out efficiency to cut the company's operational costs. Some companies adopted a downsizing policy, namely removing some of their business functions that were not directly related to the company's core business and some other companies pursuing a rightsizing policy, namely laying off some employees for efficiency [1]. Many people suddenly lose their jobs, because the company laid off most of its employees because they could not pay their salaries. Some companies also follow government policies, namely regulating employee working hours with a work from home system (work from home).

The Organization for Economic Co-operation and Development (OECD) report shows that this pandemic has an impact on the threat of a major economic crisis, marked by the cessation of production activities in many countries, decreased levels of public consumption, loss of consumer confidence, and uncertainty of stock trading. In Indonesia, the prolonged COVID-19 pandemic has an impact on economic stability throughout the region as well as in rural areas. The Covid 19 pandemic devastated a rural economic institution called Village-Owned Enterprises (BUMDes). There were 37,286 registered BUMDes and only $2 \%$ during the pandemic were able to survive. BUMDes that are able to survive in the midst of a pandemic are BUMDes that have the best strategy, agile management and management and are able to adapt to the changes that occur.

One of the BUMDes that was able to survive the midst of the Covid 19 pandemic was the Bonto Sunggumanai BUMDes (BUMDES BSM) which is located in Sunggumanai Village, Gowa Regency, South Sulawesi Province. Pre-research conducted by the research team by interviewing the BUMDes manager, namely BUMDes BSM, is still running its four business units, even opening a new business unit, namely the Horticulture business unit with the concept of "Integrated 
Agricultural Space Patterns" in October 2020 and based on data from the Ministry of Health.go.id is one of the sources of income for Sunggumanai Village in 2020 through profit sharing

This is what shows the existence of BUMDes BSM to date since its formation in 2017 and has won an award as BUMDes Achievement by the Provincial Government of South Sulawesi in 2019. Based on this, researchers are interested in conducting research on how BUMDes BSM is able to survive and remain to make a profit amid the covid 19 pandemic?

\section{RESEARCH METHODS}

The method used in the study used a qualitative descriptive approach. This research was focused on five business units from various sectors such as village financial institutions, agricultural trade, online payment services, small industries, agribusiness and horticulture business units. Through a comparison between the practices of the five business units before and during the pandemic. A qualitative descriptive approach is used to provide an overview of the real conditions of research problems by conducting observations and interviews with the Village Heads, Managers, administrators and BUMDes stakeholders. The process of obtaining information, both primary and secondary data, took several months.

A qualitative descriptive approach is used to provide an overview of the real conditions of research problems by conducting observations and interviews with the Village Heads, Managers, administrators and BUMDes stakeholders. The process of obtaining information, both primary and secondary data, took several months. The accuracy and credibility of qualitative research is carried out through verification techniques and data validity to draw conclusions and recommendations.

\section{FINDING AND DISCUSSION}

\section{A. Diversification of the Five Business Units BUMDES Bonto Sunggumanai}

Business diversification of BUMDEs BSM is inseparable from the strategy in selecting what businesses to develop. Empowering the local potential of the village through the use of available resources. There are four business units owned by BUMDes since 2017 and one new business unit in 2020.

1) Village microfinance institution service business unit: This business unit operates in the form of a financial institution by providing business capital loans to micro and small businesses and to agricultural businesses owned by local communities with low interest rates. In running this business unit, BUMDes channels funds in the form of initial capital loans or additional business capital to the public at a fixed interest rate, without the need for a certificate of ownership of goods. The approval process for the provision of village microfinance loan capital is carried out by implementing the
SOP that has been determined by the BUMDes management. Requirements to be granted business capital loans are residents of Sunggumanai village as evidenced by Identity Cards and Family Cards, owning a rice field business that is known to the local hamlet head, conducting a loan feasibility survey by business unit managers, and a stamped loan and credit agreement is made.

There are two types of lending, namely:

- Capital Loans to MSMEs, aimed at all MSMEs or village communities in the area of Sunggumanai Village who need additional capital or venture capital.

- Farming Business Credit, this loan model is specifically given to farmers who need capital to manage their fields during the planting season in the form of purchasing fertilizers, rice seeds and pesticides. Where the return on the KUT capital loan is carried out for 4 months after the harvest season with returns in the form of grain produced by farmers in the amount of capital lent by BUMDes.

2) Agricultural and plantation products trading business unit: This business unit operates in the form of trading in agricultural products, BUMDes buys community agricultural products according to market prices and the price of the Bulog (Logistics Agency). In the 2019 harvest season, BUMDes buys local grain for Rp.4,100 / kg and then sells it for Rp.4,200 / kg to buyers.

The area of productive agricultural land in Sunggumanai Village is quite extensive, around 230 hectares. The agricultural land in this village has been supported by an irrigation system, two dams, and one overflow. Sunggumanai Village can produce 1,500 tons of unpulled rice per season or one harvest. This business unit only works twice a year, namely during the harvest season for farmers in Sunggumanai Village.

3) Community service business unit: This business unit is the first business opened by BUMDes BSM, which is engaged in online payment services to facilitate people to pay their monthly bill obligations such as electricity payments, PDAM, BPJS and become BRI Link Agents. Every online payment transaction will be subject to an administrative fee that is affordable by residents. So that the existence of an online payment service unit makes it easier for villagers to pay their obligations on time.

When this first business unit was run, in the form of official online payment counter services and BRI-Link agents, the community not only got online payment services but also received information from BUMDes officers who introduced the BUMDes to help the people of Sunggumanai Village, and get input from villagers the service needs that will be developed into a BUMDes business unit in the future

4) Small industry and handicraft business unit: The business units for the production of paving blocks, castin 
concrete, and bricks are run by BUMDes BSM professionally by producing quality paving blocks that are of good standard and have gone through laboratory tests of construction materials at the Office of Bina Marga and Bina Konstruksi of South Sulawesi Province. The biggest market paving block from BUMDes BSM is the construction industry, namely the Housing Developers in the Kab. Gowa, Makassar City and Kab. Maros.

For the handicraft business, BUMDes BSM is currently producing and introducing bamboo handicrafts typical of Sunggumanai Village in the form of tumblers, glasses and ashtrays. By inviting experts in the field of bamboo handicrafts who provide education to residents to make crafts from quality bamboo-based materials. This handicraft business has received a good response from several potential buyers, namely the District Government. Gowa, Open Marketplace and Lazada, as well as an exclusive restaurant located in Gowa Regency.

5) Agribusiness and horticultural culture business unit: This fifth business unit is a new business unit initiated in 2020 by BUMDes BSM with the concept of "Integrated Agricultural Spatial Patterns", namely in one land there are integrated agriculture, fisheries and livestock businesses. An area of 1,300 square meters has been planted with various types of vegetables such as lettuce, peppers, red onions, there is also a place to grow grapes and cattle farms and catfish ponds. The concept of "Integrated Agricultural Space Pattern" is an interesting innovation from BUMDes where there are cattle farms where the manure can be used as natural compost for organic horticultural crops so that there is no need for chemical fertilizers.

\section{B. Business Diversification Strategy is a Solution For BUMDes Bonto Sunggumani to Survive the Pandemic}

Every organization, including BUMDes, has its own vision, mission and objectives, but due to the dynamic nature of the organization environment, a comprehensive strategy is needed to anticipate rapid and complex environmental changes so that the organization can always operate to achieve its goals. The success of BUMDes is determined by the strategy taken. Strategy can be interpreted as a direction of goals, or an action plan to optimize the power of resources to seize opportunities and or overcome challenges and obstacles from the organizational environment to achieve goals [2].

The survival strategy is the direction of action taken by an organization so that its business can continue to operate in a highly competitive organizational environment full of challenges and obstacles. Small and micro enterprises such as BUMDes have a fairly strong ability to survive because of the nature of the small industry itself which is directly managed by its founders so that it is more flexible and adaptable to environmental changes.

BUMDes BSM, which at the beginning of its establishment was engaged in a community service business unit in the form of official online payment counters and BRI-Link agents, developed into five different but interrelated business units. Two business units in the agricultural sector, two business units in financial services and one business unit for bamboo craftsmen. The selection of the five business units shows the business diversification strategy at BUMDes BSM. A company with business diversification refers to a company that has several different business units to take opportunities in its business environment to increase profits and company value. Griffin [3], Hitt et al. [1], Pearce and Robinson [4], David [5] divide business diversification strategies into two categories, namely concentric diversification and conglomeration diversification Concentric diversification is a company diversification strategy into other businesses that are different but still closely related to the previous business, so it is possible to develop a strategic fit among the businesses. Meanwhile, conglomeration diversification is a diversification strategy that prefers unrelated business portfolios to get investment opportunities and gain big profits. The main difference between the two strategies is that concentric diversification emphasizes some similarities in terms of products, markets and technology, while conglomerate diversification is primarily based on profit considerations [4].

The application of concentric diversification has three advantages. First, this strategy reduces the organization's dependence on one business activity, thereby reducing economic risk. Even if one or two of the company's businesses are losing money, the entire organization can survive, because a healthy business generates sufficient funds to support other businesses. During the Covid 19 pandemic, the BUMDes BSM financial institution service business unit whose core business was providing loans to rural communities did not provide any profit at all due to the community's inability to pay loan obligations. However, the other three business units, namely the online payment business unit, the agricultural product trading business unit, and the people's handicraft small industry business unit are still running and providing benefits for BUMDes BSM.

Second, by managing several related business units simultaneously, an organization can reduce the overhead costs associated with managing a single business. In other words, if the normal management costs required to run any business (such as financing services and agricultural trading) could be spread out among many businesses, then the indirect costs of doing business would be lower than the indirect costs of each business. Therefore, the related diversified firm's business overheads are usually lower than the costs of similar businesses that do not belong to large firms [3]. BUMDes BSM combines related activities from its different business units into one operating value chain to achieve lower operating costs [5].

Third, related diversification allows companies to harness the power of resources together in a variety of separate business units. If companies do this successfully, they will take advantage of synergies, which is a complementary effect between their businesses. When the economic value of the company is greater than the economic value of individual business units, synergies are created in the company's business 
value chain. BUMDes BSM optimizes the capabilities of its resources as well as strong coordination among the activities of the managed business units (production, marketing and distribution) to create profit and business unit growth [6]. In line with this opinion, Harberg and Rieple [7] suggest that business diversification is carried out with the aim of obtaining company growth and generating added value from related and integrated business units, spreading the company's business risks, and to controlling the distribution of company suppliers.

\section{CONCLUSION}

The results of the study concluded that the implementation of the business diversification strategy made BUMDes Bonto Sunggumanai able to withstand the pressure of the Covid 19 pandemic. The synergy of the village government, BUMDes, and the community made BUMDes Bonto Sunggumanai able to carry out its function as a social and commercial institution for the surrounding community. Strong leadership and innovation from the Village Head of Bonto Sunggumanai were able to realize synergistic collaboration between village government officials, BUMDes administrators, and the Bonto Sunggumanai community to optimize village potential and develop local wisdom in the village of Bonto Sunggumanai.

The results of the study provide recommendations for BUMDes BSM to implement a wide variety of concentric diversification strategies by continuously making innovations to develop other new business units and optimize the potential and local wisdom of the village of Bonto Sunggumanai. Product development, market development, as well as upstream and downstream integration are strategic choices that can be developed by BUMDes BSM to survive a pandemic. The innovative leadership of the village head and good management of BUMDes is the infrastructure for developing BUMDes businesses that will help the village economy and increase regional economic growth and equity.

\section{REFERENCES}

[1] M.A. Hitt, R.D. Ireland, S.M. Camp, and D.L. Sexton, "Strategic entrepreneurship: Entrepreneurial strategies for wealth creation," Strategic Management Journal, vol. 22, no. 6-7, pp. 479-491, 2001.

[2] N. Kamariah, M.S. Idrus, M. Asdar, and I. Sudirman, "An Inquiry on the Effect of Knowledge Management and Strategic Leadership on Dynamic Capability, Entrepreneurship Strategy and Organizational Performance in the General Public Hospitals," Journal Business and Management vol. 12, no. 1, pp. 1-12, 2013.

[3] J. Griffin, Customer Loyalty How to Earn It, How to Keep It. Kentucky: McGraw Hill, 2002.

[4] I.I. Pearce, A. John, and R.B. Robinson, Strategic Mnagement; Formulation, Implementation, and Control. 10th edition. McGraw-Hill Companies, Inc., 2007.

[5] F.R. David, Strategic Management., Pearson Education Inc. Upper Saddle River, New Jersey, 2009.

[6] J.D. Hunger and T.L. Wheelen, Essentials of strategic management (Vol. 4). New Jersey: Prentice Hall, 2003.

[7] S. Isrososiawan, "Pengaruh Pengembangan Usaha Koperasi Terhadap Peningkatan Sisa Hasil Usaha Pada Koperasi Pegawai Republik Indonesia (KPRI) Iain Mataram," Society, vol. 5, no, 1, pp. 25-38, 2014. 